\title{
PLANT GROWTH PROMOTING RHIZOBACTERIA (PGPR) DARI AKAR BAMBU APUS (Gigantochola apus) MENINGKATKAN PERTUMBUHAN TANAMAN
}

\author{
Elza Yulistiana ${ }^{1}$, Hening Widowati ${ }^{2}$, Agus Sutanto ${ }^{3}$ \\ Program Studi Pendidikan Biologi, Pascasarjana Universitas Muhammadiyah Metro \\ e-mail ${ }^{1}$ yulistianaelza@gmail.com, ${ }^{2}$ hwummetro@gmail.com, ${ }^{3}$ sutanto11@gmail.com
}

\begin{abstract}
Abstrak: Makhluk hidup membutuhkan nutrisi untuk tumbuh dan daya tahannya. Keberadaan unsur hara di sekitar akar tanaman sangat penting bagi mikroorganisme sebagai agen pengendali hayati dan juga bagi patogen tanaman. PGPR Plant Growth Promoting Rhizobacteria (PGPR) berperan dalam meningkatkan pertumbuhan tanaman, hasil tanaman dan pertumbuhan tanaman. Bakteri di PGPR dapat secara aktif menjajah rhizosfer. Akar bambu dijajah oleh banyak bakteri (Pseudomonas fluorescens), bakteri tersebut dapat berperan dalam meningkatkan kelarutan $\mathrm{P}$ dalam tanah, strain tertentu Pseudomonas sp. dapat mencegah tanaman dari jamur patogen yang berasal dari tanah. Rhizobacteria dari Bacillus spp. dan Pseudomonas spp., mampu melarutkan fosfat, sedangkan Serratia spp. kelompok, selain dapat meningkatkan ketersediaan P (fosfat) juga dapat memfiksasi nitrogen dan mampu mensintesis IAA. Mikroba yang memiliki kemampuan menghasilkan fitohormon merupakan salah satu upaya untuk membantu meningkatkan pertumbuhan tanaman.
\end{abstract}

Kata Kunci: Akar bambu apus, pertumbuhan, PGPR

\begin{abstract}
Living things need nutrients to grow and their endurance. The presence of nutrients around plant roots is very important for microorganisms as biological control agents and also for plant pathogens. PGPR Plant Growth Promoting Rhizobacteria (PGPR) has a role in increasing plant growth, crop yields and plant growth. Bacteria in PGPR can actively colonize the rhizosphere. Bamboo roots are colonized by many bacteria (Pseudomonas fluorescens), these bacteria can play a role in increasing the solubility of $P$ in the soil, certain strains of Pseudomonas sp. can prevent plants from fungal pathogens that come from the soil. Rhizobacteria from the Bacillus spp. and Pseudomonas spp., able to dissolve phosphate, while the Serratia spp. group, in addition to being able to increase the availability of $P$ (phosphate) can also fix nitrogen and be able to synthesize IAA. Microbes with the ability to produce phytohormone are an effort to help in increasing plant growth.
\end{abstract}

Keyword : Bamboo roots, growth, PGPR

\section{How to Cite}

Yulistiana, Elza, Hening Widowati, dan Agus Sutanto. 2020. Plant Growth Promoting Rhizobacteria (PGPR) dari Akar Bambu Apus (Gigantochola apus) Meningkatkan Pertumbuhan Tanaman . Biolova 1(1). 1-7. 
Makhluk hidup memerlukan nutrisi untuk tumbuh dan daya tahan hidupnya. Tanah merupakan salah satu tempat hidup mikroorganisme yang memerlukan nutrisi untuk hidup. Keberadaan nutrisi disekitar perakaran tanaman sangat penting bagi mikroorganisme agen pengendali hayati dan juga bagi patogen tanaman. Interaksi yang terjadi antara agen pengendali hayati dan patogen tanaman biasanya terjadi pada tempat tertentu, yang tidak jauh letaknya dari akar tanaman. Termpat daerah terjadinya interaksi tersebut dikenal dengan istilah rhizosfer. Kedudukan rhizofer dan peranan-nya bagi mikroba tanah secara umum sangat berbeda antar tanaman. Area rhizosfer dicirikan dengan aktivitas biologi yang paling tinggi pada tanah. Lingkungan rhizosfer ditentukan oleh interaksi dari tanah, tanaman, dan organisme yang berhubungan dengan akar Lynch (1990 dalam Soesanto, 2008: 33).Teknologi yang sedang pesat perkembangannya saat ini adalah peman-faatan mikroorganisme yang dieksplorasi dari rhizosfer tanaman (rhizobakteri) yang dapat memacu pertumbuhan tanaman, seperti PGPR. PGPR Plant Growt Promoting Rhizobacteria (PGPR) berperan meningkatkan pertumbuhan tanaman, hasil panen dan pertumbuhan tanaman. Bakteri pada PGPR dapat secara aktif mengkolonisasi rizosfer. Selain itu bakteri tersebut dapat sebagai biofertilizer, yaitu mampu mempercepat proses pertumbuhan melalui percepatan penyerapan unsur hara. Kemudian sebagai biostimulan yaitu PGPR dapat memicu pertumbuhan tanaman dengan cara memproduksi fitohormon pertumbuhan. PGPR juga melindungi tanaman dari serangan patogen (Shofiah dan Tyasmoro, 2018:76).
Sejalan dengan pendapat Arshad \&Frankenberger (1993 dalam Firmansyah, dkk. 2015: 144) bakteri pada PGPR di antaranya Psedomonas $s p$. pada beberapa strain tertentu dapat mencegah tanaman dari serangan patogen berupa fungi di dalam tanah sekitar akar tanaman, sehingga tanaman dapat lebih tahan terhadap serangan penyakit berupa jamur tanaman.PGPR juga dapat digunakan sebagai pupuk hayati yang biasa ditumbuhkan di dalam substrat cair sebagai pupuk cair dan mudah diserap oleh akar tanaman dibandingkan dengan pupuk padat (Figuiredo, dkk. 2010 dalam Naihati, dkk. 2018:1).

PGPR dapat menggunakan akar bambu, akar bambu banyak terkolonisasi oleh bakteri PF (Pseudomonas fluorescens), dimana bakteri ini dapat meningkatkan kelarutan $\mathrm{P}$ dalam tanah (Pratiwi, dkk. 2017: 78). Pemberian PGPR memudahkan unsur $P$ larut dalam tanah dan dapat dengan mudah diserap oleh akar tanaman. Unsur $\mathrm{P}$ dalam tanah diperlukan tanaman dalam memenuhi nutrisi tanaman sehingga apabila keperluan unsur $\mathrm{P}$ terpenuhi maka tanaman akan tumbuh dengan baik.

Tujuan dari penulisan artikel ini adalah untuk mengetahui Plant Growth Promoting Rhizobacteria (PGPR) dari akar bambu Apus (Gigantochola apus)dapat meningkatkan pertumbuhan tanaman.

\section{METODE}

Metode yang digunakan dalam artikel ini adalah studi dokumentasi mengkaji beberapa artikel yang berhubungan dengan Plant Growth Promoting Rhizobacteria (PGPR) dari akar bambu Apus (Gigantochola apus). 


\section{HASIL KAJIAN DAN PEMBAHASAN}

\section{Bambu Apus (Gigantochola apus)}

Tanaman bambu tumbuh dengan membentuk rumpun, di Indonesia tersedia secara melimpah bambu yang dapat dimanfaatkan batangnya untuk memenuhi kebutuhan manusia. Bambu dapat tumbuh di daerah iklim basah sampai kering, dari daratan tinggi dan biasnya di tempattempat terbuka. Manfaat bambu sering digunakan batangnya sebagai bahan kerajianan. Jenis bambu yang dikenal masyarakat beragam di antaranya bambu Apus (Gigantochola apus). Jenis bambu ini banyak tumbuh di sekitar lingkungan masyarakat. Pemanfaatan bambu tersebut digunakan untuk tali, bahan bagunan dan kerajinan alat rumah tangga maupun hiasan rumahan. Setelah pemanfaatan batang bambu sering kali akar bambu sendiri terabaikan bahkan tidak dimanfaatkan karena dapat menghasilkan tanaman bambu yang baru. Selain hal tersebut akar bambu dapat dimanfaatkan sebagai pupuk alami karena terkoloni banyak bakteri di rizhosfer yaitu daerah perakaran yang dapat membantu tanaman untuk meningkatkan pertumbuhan-nya.

Secara morfologi bambu
mempunyai batang beruas dan berbuku. Pada setiap ruas tumbuh cabang-cabang yang berukuran kecil daripada batang bambunya sendiri. Batang bambu tumbuh tegak, terdapat pelepah yang memruakan modifikasi daun yang menepel pada setiap ruas. Pelepah ini berfungsi menutupi batang ketika muda. Sedangkan daun pada bambu memiliki urat daun sejajar seperti rumput, setiap daunnya mempunyai tulang utama yang menonjol. Akar pada bambu memiliki rimpang, rimpang merupakan batang di dalam tanah, sebagian kuncup pada rimpang muncul kepermukaan menjadi buluh. Kuncup yang tumbuh dari rimpang akar bambu akan menjadi rebungyang lambat laun kan menjadi buluh (Abrori, 2016: 11). Berikut ini Gambar 1 bambu Apus.

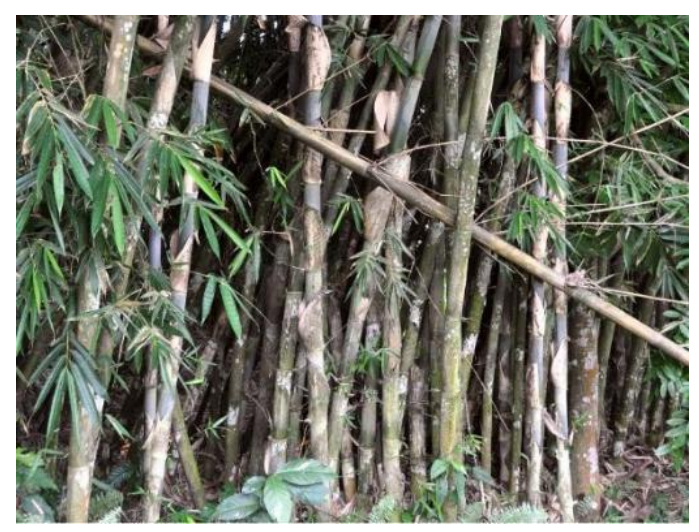

Gambar 1. Bambu Apus (Gigantochola apus)

Sumber: id.wikipedia.org

\section{Rizhosfer}

Kualitas biologi (bahan
organik) tanah meningkat dengan adanya mikroorganisme tanah terutama pada area rhizosfer. Menurut Simatupang (2008: 12), rhizosfer merupakan bagian tanah yang berada di area sekitar perakaran tanaman. Populasi mikroorganisme di area rhizosfer umumnya lebih banyak dan beragam dibandingkan pada tanah nonrhizosfer.

Aktivitas mikroorganisme rhizosfer dipengaruhi oleh nutrisi yang dihasilkan oleh perakaran tanaman budidaya. Beberapa mikroorganisme rhizosfer berperan dalam siklus hara, kualitas tanah, proses pembentukan tanah, memengaruhi aktivitas mikroorganisme, pertumbuhan 
tanaman, serta sebagai pengendali hayati terhadap penyakit pada akar.Hubungan antara organisme seperti rhizobakteri dan akar dapat menguntungkan, maupun merusak, atau tidak berdampak apapun tetapi seiring pengaruhya tergantung pada kondisi tanah.Hal ini ditentukan oleh kondisi tanah yang beragam yang dapat mempengaruhi pertumbuhan tanaman dan pertumbuhan mikroba di dalam tanah. Berikut ini adalah Gambar 2. Hubungan antara tanaman, organisme, dan tanah terhadap rhizosfer.

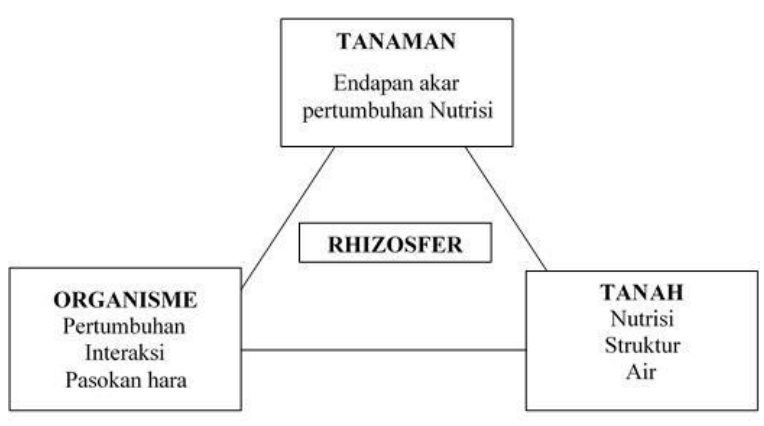

Gambar 2. Hubungan Segitiga antara Tanaman, Organisme, dan Tanah terhadap Rhizosfer.

(Sumber: Soesanto, 2008: 33).

Pada gambar 2 menjelaskan bahwa jenis tanaman berpengaruh pada macam organismenya dan ditentukan oleh tanahnya. Setiap faktor memiliki perbedaan yang ditentukan oleh masing-masing factor pembedanya. Tanaman misalnya, ditentukan oleh nutrisi yang diserapnya, yang akan berpengaruh pada eksudat yang dikeluarkan oleh akar. Jenis dan jumlah eksudat di tentukan oleh jenis tanamannya. Begitu pula faktor tanah, struktur tanah sangat menentukan pertumbuhan tanaman karena kemampuan perakaran tanaman untuk tumbuh menembus ke dalam tanah.
Selain itu, nutrisi dan udara di tanah berperanan penting bagi pertumbuhan tanaman, dan juga bagi organismenya. Adanya eksudat akar dan didukung dengan lingkungan di dalam tanah, akan memengaruhi pertumbuhan dan interaksi pertumbuhan, khususnya mikroba tanah, dengan tanaman dan tanah (Soesanto, 2008: 33). Eksudat meliputi gula, asam amino dan aromatik yang dikeluarkan oleh sel ke ruang diantara sel dan tanah di sekitarnya (Widyati, 2013: 17).

Tujuan akhir dalam memanipulasi rhizosfer adalah untuk meningkatkan keseimbangan pengaruh mikroba tanah yang menguntungkan dan membahayakan. Hal yang menguntungkan seperti aktivitas rhizobakteri berperan penting dalam kesuburan tanah dan produktivitas tanaman. Kemampuan tanah untuk meningkatkan pertumbuhan tanaman didasarkan pada keberadaan dan keseimbangan banyak senyawa seperti Fosfor (P), Kalsium (K), Sulfur (S), dan Natrium (Na) diketahui bahwasenyawa tersebut sangat dibutuhkan oleh tanaman untuk tumbuh dan berkembang. Senyawa tersebut dapat diuraikan oleh mikroba sehingga dapat dengan mudah diserap dan digunakan oleh tumbuhan. Tersediaan senyawa tersebut di dalam tanah tidak semuanya dapat di serap dan digunakan secara optimal oleh tanaman. Maka bakteri tanah berperan untuk menguraikannya. Bakteri bermanfaat untuk merombak dan mendaur ulang senyawa-senyawa ini.

\section{Plant Growth Promoting Bacteri (PGPR)}

\footnotetext{
Penggunaan PGPR berkaitan dengan kemampuannya mengkoloni perakaran
} 
tanaman. Rhizobakteri harus dapat menyelubungi seluruh permukaan akar agar dapat mengkoloni akar tersebut. Kemudian akar akan menyerap produk dalam mikroba yang secara langsung mempengaruhi pertumbuhan dan fisiologi akar serta mempengaruhi terhadap serangan patogen.

Akar bambu banyak terkolonisasi bakteri (Pseudomonas fluorescens), bakteri ini dapat berperan meningkatkan kelarutan $\mathrm{P}$ dalam tanah, Strain tertentu dari Pseudomonas sp. dapat mencegah tanaman dari patogen fungi yang berasal dari tanahArshad \& Frankenberger (1993 dalam Firmansyah, dkk.2015: 144). Bakteri (Pseudomonas fluorescens) juga mengeluarkan atibiotik untuk menekan pertumbuhan patogen berupa jamur (anti jamur) (Soesanto, 2011).

Patogen akar umumnya bersifat tular tanah dan menyebabkan penyakit pada akar tanaman dengan mekanisme mengganggu sistem perakaran yang menyebabkan tanaman tersebut mati. Patogen tersebut dapat berasal dari mikroba yang berupa jamur maupun bakteri. PGPR disebut juga sebagai agensi pengendali hayati karena kemampuannya untuk menekan pertum-buhan patogen yang menyerang tanaman. Agensia pengendali hayati dengan patogen yang menyerang akar tanaman bersifat antagonisme. Contohnya antagonisme tersebut adalah Streptomyces scabies, penyakit penyakit kudis kentang, ditekan alami oleh populasi Bacillus subtilis. Mikroba lainnya yang menekan perumbuhan penyakit oleh jamur adalah spesies Pseudomonas dan Basillus. Mikroba bersifat antaginis tersebut dapat menekan pertumbuhan patogen sehingga berimbas kepada ketahanan tanaman terhadap patogen (Soesanto, 2008: 166).
Mikroba PGPR dari sebuah akar tanaman berasal dari beberapa genus berbagai jenis bakteri telah diidentifikasi sebagai PGPR. Sebagian besar berasal dari kelompok gramnegatif dengan jumlah strain paling banyak dari gen Pseudomonas dan beberapa dari genus Serratia. Selain kedua genus tersebut, dilaporkan antara lain genus Azotobacter, Azospirillum, Acetobacter, Burkholderia, Enterobacter, Rhizobium, Erwinia, Flavobacterium dan Bacillus (Wahyudi, 2009 dalam Ranhi, 2012: 27). Sebagai contoh Pseudomonas aureofacienns yang memproduksi antibiotika fenazin dan kemudian secara langsung diserap oleh akar tanaman tomat dan menumpuk pada sel korteks.

Hasil percobaan Ernita, M., T. Habazar., Nasrun dan Jamsari., (2015) didapatkan 2 isolat rhizobakteri indigenus yaitu Pseudomonas genophilata dan Bacillus pumilus mampu menginduksi ketahanan, meningkatkan pertumbuhan dan hasil bawang merah secara in planta. Pengembangan rhizobakteri sebagai agen hayati dan meningkatkan pertumbuhan telah banyak. Beberapa peneliti melaporkan bahwa rhizobakteri dari kelompok Bacillus spp. dan Pseudomonas spp., mampu melarutkan fosfat, sedangkan kelompok Serratia spp., selain mampu meningkatkan ketersediaan $\mathrm{P}$ (Posfat) juga dapat memfiksasi nitrogen dan mampu menyintesis IAA. Ketersediaan Pospat dapat ditingkatkan dengan pemanfaatan mikroba pelarut fosfat. Mikroba tersebut selain dapat menghasilkan enzim fosfatase juga dapat mengeluarkan asam-asam organik. Asam-asam organik tersebut seperti: asam sitrat, glutamat, suksinat, tartat, format, asetat, propionat, laktonat, 
glikonat dan fumarat. Asam-asam organik ini akan bereaksi dengan

$\mathrm{FePO}_{4}$, yang dapat membentuk khelat (kompleks stabil) dengan kation-kation pengikat $\mathrm{P}$ di dalam tanah seperti $\mathrm{Fe}^{3+}$. Akibatnya dapat menurunkan reaktivitas ion ion dan menyebabkan pelarutan yang efektif sehingga $P$ yang terfiksasi dapat tersedia untuk tanaman (Setiawati, dkk. 2014:31). Fosfat di dalam tanah merupakan unsur hara yang berperan penting bagi proses pertumbuhan tanaman. Ketersediaan unsur fosfat dibantu oleh bakteri pelarut fosfat yang banyak dijumpai di daerah rizosfer (Marista, dkk. 2013: 93). Bakteri pelarut fosfat merupakan bakteri dekomposer yang berperan dalam penyuburan tanah karena mampu melakukan mekanisme pelarutan fosfat dengan mengekskresikan sejumlah asam organic berbobot molekul rendah. Bakteri memanfaatkan senyawa karbon sederhana (eksudat dari akar tanaman dan sisa dari tanaman) (Ilham, dkk. 2014: 173).

Isolat Bacillus spp. dan $P$. Fluorescens juga dilaporkan mampu menyintesis hormon tumbuh IAA, sitokinin , dan giberelin(Sutariati, dkk. 2006: 46). Hormon-hormon tumbuhan tersebut dapat diamakan dengan ftohormon. Hormon pada tumbuhan yang mengatur pertumbuhan dan perkembangan. Sesuai dengan perndapat (Kukreja et al., 2004 dalam Widyati 2016: 11) Fitohormon secara alami meliputi tiga kelompok senyawa utama, yaitu auksin, giberelin dan sitokinin. Produksi hormon tumbuhan tidak hanya diproduksi dalam tumbuhan itu saja namun mikroba yang ada di dalam tanah di daerah rhizozfer. Hormon dalam tumbuhan dapat dipicu dengan menggunakan bakteri dalam tanah yaitu rizhobakteri yang berada di rizhosfer dinamakan PGPR. Mikroba dengan kemampuan menghasilkan fitohormon tersebut merupakan upaya untuk membantu dalam meningkatkan pertummbuhan tanaman.

\section{KESIMPULAN}

PGPR mengandung bakteri Bacillus spp. dan P. Fluorescens yang mampu menyintesis hormon tumbuh IAA, sitokinin, dan giberelin yang merupakan hormon pertumbuhan tanaman, sehingga dapat meningkatkan pertumbuhan tanaman.

\section{SARAN}

Penelitian mengenai PGPR agar dilakukan lebih mendalam mengenai perannya untuk pertumbuhan tanaman dari akar tanaman yang beragam.

\section{DAFTAR RUJUKAN}

Firmansyah, I; Liferdi; Khaririyatun, N; dan Yufdy MP. 2015. Pertumbuhan dan Hasil Bawang Merah dengan Aplikasi Pupuk Organik dan Pupuk Hayati pada Tanah Alluvial. Jurnal Hort. Volume 25 Nomor 2. Bandung: Balai Penelitian Tanaman Sayuran.

Marista, Etha; Siti Khomariah; dan Riza Linda. 2013. Bakteri Pelarut Fosfat Hasil Isolasi dari Tiga Jenis Tanah Rizosfer Tanaman Pisang Nipah (Musa paradisiaca var. nipah) di

Kota Singkawang. Jurnal Protobiont. Volume 2 nomor 2. Pontianak: Universitas Tanjung-pura. 
Naihati, Yohanes F.; Roberto I. C. O. Taolin; dan Aloysius Rasae. 2018. Pengaruh Takaran dan Frekuensi Aplikasi PGPR terhadap Pertumbuhan dan Hasil Tanaman Selada (Lactuca sativa L.). Jurnal Pertanian Konservasi Lahan Kering. Volume 3 Nomor 1. NTT. Universitas Timor.

Pratiwi, Fitrah; Marlina dan Mariana. 2017. Pengaruh Pemberian Plant Growth Promoting Rhizobakteria (PGPR) dari Akar Bambu terhadap Pertumbuhan dan Hasil Bawang Merah (Allium ascalonicum L.). Jurnal Agrotropika Hayati.Volume 4 Nomor 2. Aceh: Universitas Almuslim.

Rahni, Nini Mila. 2012. Efek Fitohormon PGPR terhadap Pertumbuhan Tanaman Jagung (Zea mays). Jurnal Agribisnis dan Pengembangan Wilayah Volume 3 Nomor 2. Kendari: Universitas Haluoleo.

Shofiah,Dian Khoirotun dan Setyono Yudho Tyasmoro. 2018. Aplikasi PGPR (Plant Growth Promoting Rhizobacteria) dan Pupuk Kotoran Kambing pada Pertumbuhan dan Hasil Bawang Merah (Allium ascalonicum L.) Varietas Manjung. Jurnal produksi Tanaman. Volume. 6 Nomor 1. Malang: Universitas Brawijaya.

Setiawati, M.R. ; Suyatmana; P. Hendersah; R. Fitriati; B.N dan Hendiyantoro, D. 2014. Karakterisasi Isolat Bakteri
Pelarut Fosfat untuk Meningkatkan Ketersedian $\mathrm{P}$ pada Media Kultur Cair Tanaman Jagung (Zea mays L.). Jurnal Bionatura volume 16 nomor 1. Bandung: Universitas Padjajaran.

Sutariati, Gusti Ayu Kade; Widodo; Sudarsono; dan Satriyas Ilyas. 2006. Pengaruh Perlakuan Rizo- bakteri Pemacu Pertumbuhan Tanaman terhadap Viabilitas Benih serta Pertumbuhan Bibit Tanaman Cabai. Jurnal Bul. Agron. Volume 1 Nomor 34.

Soesanto, Loekas. 2008. Pengantar Pengendalian Hayati Penyakit Tanaman. Jakarta: RajaGrafindo Persada.

Widyati, Enny. 2013. Memahami Interaksi Tanaman-Mikroba. Jurnal Tekno Hutan Tanaman. Volume 6 Nomor 1. Bogor: Pusat penelitian Pengembangan Peningkatan Produktivitas Hutan. 